\title{
DYE ABILITY OF SOME FABRIC MATERIALS (COTTON, POLYESTER AND COTTON/ POLYESTER BLEND) USING SOME NATURAL DYES IN AN ECONOMICAL DYEING PROCESS ${ }^{1}$
}

\author{
AMAL S. MOHAMED
}

Cotton Research Institute - ARC - Giza

(Manuscript received 16 June 2009)

\begin{abstract}
The present study utilizes natural dyestuffs which would not contribute to environmental pollution and undertaken to explore promising approach to reduce costs of dye process. However, the natural dyes of henna and onion skin were used to dye different fabric materials, i.e $100 \%$ cotton, $100 \%$ polyester and $35 \%$ cotton / $65 \%$ polyester blend. The low temperature $30^{\circ} \mathrm{C}$ and the high temperature $100{ }^{\circ} \mathrm{C}$ under closed dyeing system were applied in this study. The results indicated that, using the natural dyes (henna and onion skin) with the previously mentioned fabrics under the low temperature $\left(30^{\circ} \mathrm{C}\right)$ resulted in an increase in fabric strength of the $100 \%$ cotton fabric and the $35 \%$ cotton / $65 \%$ polyester blend, while no change in fabric strength of the 100 $\%$ polyester material. Thus it appeared that using these natural dyes would not cause any deterioration in fabric strength. On the other hand, the fabric elongation was not affected by the dyeing process. While the results showed that the shrinkage values of dyed fabrics with henna were generally lower than the corresponding values of dyed fabrics with onion skin. However, all fabric materials under this study when dyed with henna and onion skin, revealed higher fastness to light and wash, lower fastness for alkali and acid perspiration. Finally, it was observed that using high temperature and closed dyeing system was not suitable for dyeing these kinds of fabrics with henna and onion skin dyes.
\end{abstract}

\section{INTRODUCTION}

Cotton fabrics are known to be more comfortable than the polyester fabrics. In recent years the cotton/polyester blends are considered as the most widely used fabrics. The presence of both components (polyester and cotton) in textile products causes some difficulties in the dyeing process. Polyester fibers have a hydrophobic character, and swell to a very small extent in the water bath. Hence, the penetration of the dyestuff molecules inside the fibers would be very difficult. This fact, together with an absence of active chemical groups in polyester's macromolecules makes it impossible to apply the majority of dyestuffs apart from disperse dyes. On the contrary, hydrophilic cellulose fibers such as cotton easily undergo swelling in water. Owing to this phenomenon, the dyestuff molecules first adsorbed on the fiber surface

\footnotetext{
${ }^{1}$ The work of this paper has been granted as patent no. (474) 2006 from Egyptian patent office
} 
may diffuse into the fiber interior. Subsequently, the bonding interactions between the dyestuff and cellulose may be formed. The application of the applied pressure method in dyeing requires a suitable, intricate apparatus which requires great energy consumption, (Swiderski, 1981).

Dyeing cotton/polyester blend fabrics with onion dyes would reduce the use of expensive machinery, consumption of water, dyes, other chemicals and energy. So it is an attractive idea to the modern dyer. Various possibilities exist for dyeing the blends: vat, sulphur, reactive, or direct dyes may be used for the cotton component after fixation of the disperse dye on the polyester component. The use of mixed dyes, i.e. ranging from carefully selected disperse and vat dyes, have gained considerable importance in continuous dyeing, since disperse dyes do not color the polyester fibers satisfactorily in the presence of a typical vat dye reducing agent. The applications of mixtures of disperse dyes and vat dyes must therefore be carried on two stages. Some problems associated with two-stage method would be represented by the large proportion of the dyes which goes onto the wrong fiber and the possibility of staining white fabrics. Further the color gamut available from the mixtures could restrict, particularly bright reds and turquoises, and it would be hardly possible to obtain solid shades on blend fabrics. The method of processing the blends with single-dye system would have a great advantage over the mixed-dyes systems ( Miksovsky, 1980).

Dyeing using natural materials dates back to over 5,000 years ago. Recently, environmental concerns have created an increasing demand for natural dyes which are more friendly to the environment than synthetic dyes (Taylor 1986, Routledge and Kegan 1979 and Isharat 1993). Sidney (1978) mentioned that, synthetic dyes have a wide range of hazardous effects. They are toxic or poisonous, corrosive (destructive to living tissues), irritants (induce local inflammatory reaction in living tissue), strong sensitizes (cause hypersensitivity on living tissues, through an allergic), flammable, explosive, infections (represent a potential source of the transmission of diseases to human, domestic animal or wild life), radioactive, carcinogenic (cause malignant tumors), mutagenic (causes heritable genetic changes), teratogenic (cause non-heritable genetic changes).

The earliest natural dyes all came from natural ingredients, such as onion skin . The most important dye substances in onion are flavonoids (quercetin), as well as, the anthocyanin, protochatechuic acid and some tannins. Red or purple outer skin of onion also contains anthocyanin, (nova, 2005).On the other hand, the henna dye is extracted from the plant Lawsonia inermis, whase color is due to the compound Lawson (2-hydroxy-1,4-naphthoquinone) (Botros et al. 2004). Rehsi and Daruvala (1957) extracted the coloring matters from henna leaves by water, and dyed the 
cotton fabric with $1.12 \%$ extractable dye. The molecular-structure of the henna dye (Lawson) and onion skin dye (anthocyanin) are shown in Figs. 1 and 2 (Botros et al., 2004 and nova, 2005).<smiles>C=C1C=C(O)C(=O)c2ccccc21</smiles>

Fig. 1. Molecular-structure of the henna dy $\epsilon, \underline{\mathrm{O}}$..ydroxy-1,4 -naphthoquinone (Comm. Name: Lawson)<smiles>[CH2+]OC1=CC2C=C(OC(C)=O)C1=Cc1c(O)cc(O)cc12</smiles>

Fig.2. Molecular-structure of onion skin dye (anthocyanin)

\section{MATERIALS AND METHODS}

\section{Materials:}

The used fabrics were $1 / 1$ plain weave: $100 \%$ cotton, $100 \%$ polyester (PET) and $35 \%$ cotton / $65 \%$ polyester blend. The cotton variety used was Giza 89. These materials were kindly supplied by Misr Spinning and Weaving Company, El-Mahala ElKubra.

Air dried leaves of henna were ground and extracted with $95 \%$ ethyl alcohol to separate the extracted dyes, and the extracted materials were transferred to vacuum rotary evaporator to remove the excess alcohol, cooling the residue for $24 \mathrm{hr}$, The cooled samples were frozen at $10^{\circ} \mathrm{C}$ for $4 \mathrm{hrs}$, on plastic trays. On the other hand, samples of red onion skin each of $100 \mathrm{~g}$ weight were boiled in one liter of soft water 
until it was reduced to $500 \mathrm{ml}$. The extracted liquor was then filtered and used in dyeing.

\section{Dyeing process :}

The natural dye was applied by immersing the scoured fabrics in a dye bath containing the dye extract (henna or onion skin) at liquor ratio of $1: 50 \mathrm{ml}$ dyeing solution for each gram of the sample, at room temperature without heating. Then at $100{ }^{\circ} \mathrm{C}$, sodium chloride was added along with copper sulfate which was added as a mordant (2-10 g/l) under closed dyeing system. Finally, the dyed samples were rinsed in soft water and then dried.

\section{Measurements:}

The color strength $(K / S)$ was measured using the Win lab Software of the Perkin Elmer, Lambda 35 spectrophotometer according to ASTM, D: 2288-93. The color fastness to light was measured according to ASTM, D: 2053-86, while the color fastness to wash and perspiration was determined according to AATCC (1998) 15-1960 and 36-1961. These properties were measured at the National Institute for Standards, Textile Department, Giza , Egypt.

Fabric strength $(\mathrm{kg})$, elongation (\%) and shrinkage (\%) of the preconditioned samples under the atmospheric conditions of relative humidity $65 \pm 5 \%$ and $20 \pm$ $1^{\circ} \mathrm{C}$ were measured at National Institute for Standards, Textile Department, Giza, Egypt according to A.S.T.M. D: 1682 (1972). The shrinkage \% of dyed fabrics was tested according to A.S.T.M. (1972).

The statistical procedures outlined by Little and Hills (1978) were applied to the data obtained in this study.

\section{RESULTS AND DISCUSSION}

The present study revealed that generally when the dyeing process was done at high temperature $\left(100^{\circ} \mathrm{C}\right)$ the appearance of the dyed fabrics was very bad. Hence it appears that using high temperature is not suitable for dyeing these kinds of fabrics with the natural dyes (henna and onion skin) under the dyeing process system in this study. Accordingly the properties of strength, elongation \%, shrinkage \%, and color strength and color fastness were not measured, in such a case.

\section{Fabric strength, elongation $\%$ and shrinkage $\%$ for the different fabrics when dyed at $30^{\circ} \mathrm{C}$ with henna and onion skin dyes:}

The results recorded in Tables 1 and 2 illustrate the values of the fabric strength $(\mathrm{kg})$ for the different types of fabric materials (100 \% cotton, $100 \%$ PET and $35 \%$ 
cotton / $65 \%$ PET blend) dyed at $30^{\circ} \mathrm{C}$ with henna and onion skin dyes. The results show that generally the undyed and dyed fabrics of the $100 \%$ cotton fabric showed lower fabric strength compared with the strength of the blended fabric (35\% cotton / $65 \%$ PET), while the $100 \%$ PET revealed the highest fabric strength value. On the other hand, the fabric strength increased significantly after dyeing with both natural dyes for the $100 \%$ cotton and the $35 \%$ cotton / $65 \%$ PET blend compared with the control, Figure (3). This may be due to yarn swelling after dyeing, so fabric strength tends to increase as more points of yarn would become more active in sharing the load as a result of swelling when tensile forces are applied to the fabric. As for the $100 \%$ PET, there was no change in fabric strength due to dyeing treatments. So these results revealed that dyeing with these natural dyes under the dyeing conditions used in this study would not cause any deterioration in fabric strength. These results, however agree with those of El-Nagar et al. 2005.

Table1. Fabric strength $(\mathrm{kg})$ of fabrics dyed with henna and onion skin dyes (effect of dye type).

\begin{tabular}{|l|c|c|c|c|c|c|}
\hline \multirow{2}{*}{ Fabric type } & \multicolumn{3}{|c|}{ Warp } & \multicolumn{3}{c|}{ Weft } \\
\cline { 2 - 7 } & $\begin{array}{c}\text { Undyed } \\
\text { fabric }\end{array}$ & $\begin{array}{c}\text { Dyed fabric } \\
\text { with henna } \\
\text { dye }\end{array}$ & $\begin{array}{c}\text { Dyed fabric } \\
\text { with onion } \\
\text { skin dye }\end{array}$ & $\begin{array}{c}\text { Undyed } \\
\text { fabric }\end{array}$ & $\begin{array}{c}\text { Dyed fabric } \\
\text { with henna } \\
\text { dye }\end{array}$ & $\begin{array}{c}\text { Dyed fabric } \\
\text { with onion } \\
\text { skin dye }\end{array}$ \\
\hline $100 \%$ cotton & 30 & 33 & 35 & 25 & 28 & 27 \\
\hline $100 \%$ PET & 51 & 51 & 51 & 39 & 39 & 39 \\
\hline $35 \%$ cotton / & 41 & 42 & 44 & 34 & 35 & 37 \\
$65 \%$ PET & 1.990 & 1.998 & 1.998 & 1.990 & 1.9979 & 1.990 \\
\hline L.S.D. 0.05\% & & & & & & \\
\hline
\end{tabular}

L.S.D. $0.05 \%=$ Least significant difference at $0.05 \%$ level.

Table 2. Fabric strength $(\mathrm{kg})$ of fabrics dyed with henna and onion skin dyes (effect of fabric material).

\begin{tabular}{|l|c|c|c|c|}
\hline Treatment & \multirow{2}{*}{$\begin{array}{c}\text { Fabric } \\
\text { direction }\end{array}$} & $\begin{array}{c}100 \% \\
\text { Cotton }\end{array}$ & $\begin{array}{c}35 \% \text { Cot } / \\
65 \% \text { PET }\end{array}$ & $\begin{array}{c}100 \% \\
\text { PET }\end{array}$ \\
\hline \multirow{2}{*}{ Control } & \multirow{3}{*}{ Warp } & 30 & 51 & 41 \\
\cline { 1 - 3 } Dyeing with henna dye & & 33 & 50 & 42 \\
\cline { 1 - 3 } Dyeing with onion skin dye & \multirow{3}{*}{ Weft } & 35 & 51 & 44 \\
\cline { 1 - 3 } Control & & 25 & 39 & 34 \\
\hline Dyeing with henna dye & 28 & 39 & 35 \\
\hline Dyeing with onion skin dye & & 1.779 & 39 & 37 \\
\hline L.S.D. 0.05\% & & 1.779 & 1.779 \\
\hline
\end{tabular}

L.S.D. $0.05 \%=$ Least significant difference at $0.05 \%$ level. 




Fig 3. Fabric strength $(\mathrm{Kg})$ of fabrics dyed with henna and onion skin dyes (effect of dye Type) .

On the other hand, it is quite clear from Tables 3 and 4 that elongation \% values of all fabric types were generally not noticeably affected after dyeing with these natural dyes. However the100 \% PET has the highest elongation \% followed by the $35 \%$ cotton / $65 \%$ PET and the $100 \%$ cotton respectively, Figure (4).

Table 3. Elongation (\%) of fabrics dyed with henna and onion skin dyes (effect of dye type).

\begin{tabular}{|l|c|c|c|c|c|c|}
\hline \multirow{2}{*}{ Fabric type } & \multicolumn{3}{|c|}{ Warp } & \multicolumn{3}{c|}{ Weft } \\
\cline { 2 - 7 } & $\begin{array}{c}\text { Undyed } \\
\text { fabric } \\
\text { with henna } \\
\text { dye }\end{array}$ & $\begin{array}{c}\text { Dyed fabric } \\
\text { onion skin dye }\end{array}$ & $\begin{array}{c}\text { Dyed fabric with } \\
\text { fabric }\end{array}$ & $\begin{array}{c}\text { Undyed } \\
\text { with henna } \\
\text { dye }\end{array}$ & $\begin{array}{c}\text { Dyed } \\
\text { fabric with } \\
\text { onion skin } \\
\text { dye }\end{array}$ \\
\hline $\begin{array}{l}100 \\
\text { cotton }\end{array}$ & 12 & 12 & 11 & 14 & 14 & 14 \\
\hline $\begin{array}{l}100 \% \text { PET } \\
\text { / cotton }\end{array}$ & 15 & 16 & 16 & 19 & 20 & 18 \\
\hline $\begin{array}{l}65 \% \text { PET } \\
\text { L.S.D. 0.05 }\end{array}$ & 2.00 & 2.00 & 2.00 & 2.00 & 2.00 & 2.00 \\
\hline
\end{tabular}

L.S.D. $0.05 \%=$ Least significant difference at $0.05 \%$ level. 
Table 4. Elongation (\%) for dyed fabrics with henna and onion skin dyes (effect of fabric material).

\begin{tabular}{|c|c|c|c|c|}
\hline Treatment & $\begin{array}{c}\text { Fabric } \\
\text { direction }\end{array}$ & $\begin{array}{l}100 \% \\
\text { Cotton }\end{array}$ & $\begin{array}{c}35 \% \text { Cot / } \\
65 \% \text { PET }\end{array}$ & $\begin{array}{c}100 \% \\
\text { PET }\end{array}$ \\
\hline Control & \multirow{3}{*}{ Warp } & 12 & 22 & 15 \\
\hline Dyeing with henna dye & & 12 & 23 & 16 \\
\hline Dyeing with onion skin dye & & 11 & 22 & 16 \\
\hline Control & \multirow{3}{*}{ Weft } & 14 & 30 & 19 \\
\hline Dyeing with henna dye & & 14 & 30 & 20 \\
\hline Dyeing with onion skin dye & & 14 & 30 & 18 \\
\hline L.S.D. $0.05 \%$ & & 1.77 & 1.78 & 1.78 \\
\hline
\end{tabular}

L.S.D. $0.05 \%$. = Least significant difference at $0.05 \%$ level.

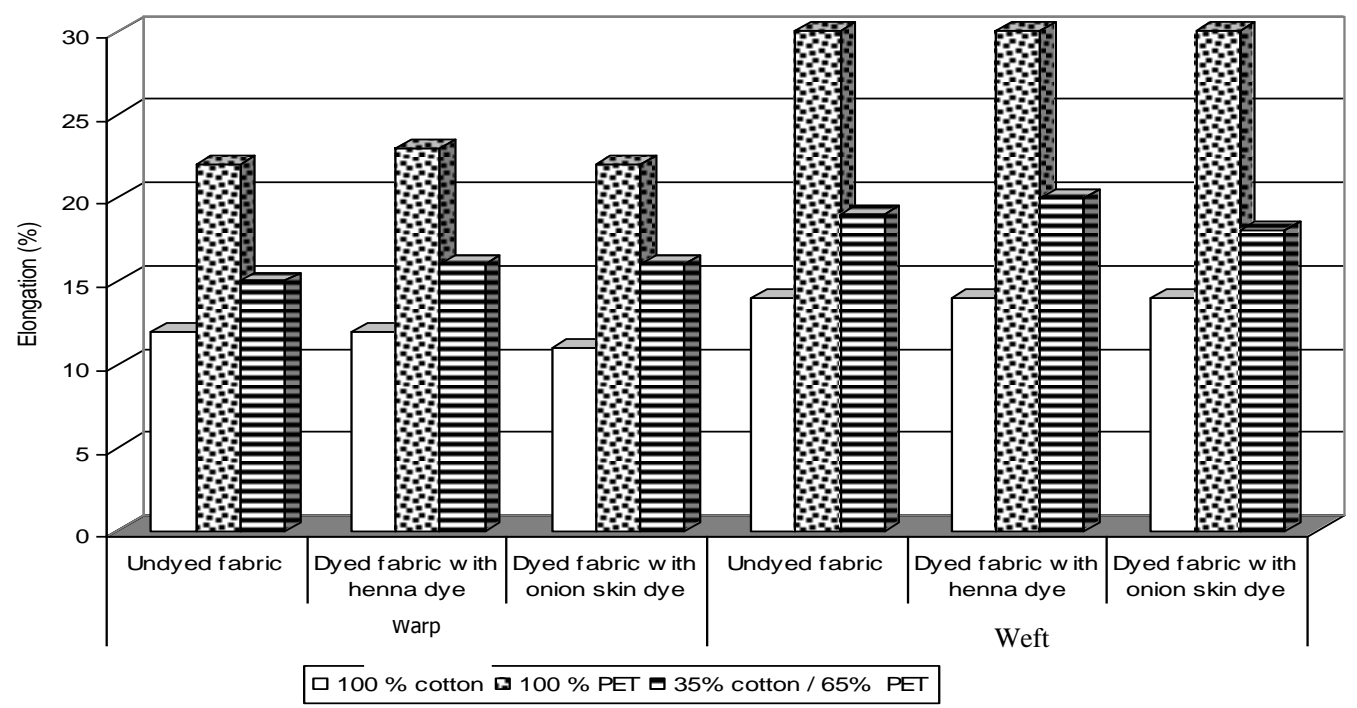

Fig.4. Elongation (\%) of fabrics dyed with henna and onion skin dyes (effect of dye type ).

Regarding the shrinkage \% Tables 5 and 6 illustrate that generally the shrinkage $\%$ for all the fabric types dyed with henna dye was lower than the shrinkage $\%$ the fabrics dyed with the onion skin dye for both directions (width and length). The highest shrinkage \% was found on the $100 \%$ cotton fabric followed by the $35 \%$ cotton / 65 \% PET blend, while the $100 \%$ PET had the lowest shrinkage \%, as shown also in Figure (5). 
Table 5. Shrinkage (\%) of fabrics dyed with henna and onion skin dye (effect of dye type).

\begin{tabular}{|l|c|c|c|c|}
\hline \multirow{2}{*}{ Fabric type } & \multicolumn{2}{|c|}{ Width } & \multicolumn{2}{c|}{ Length } \\
\cline { 2 - 5 } & $\begin{array}{c}\text { Dyed fabric } \\
\text { with henna } \\
\text { dye }\end{array}$ & $\begin{array}{c}\text { Dyed fabric } \\
\text { with onion skin } \\
\text { dye }\end{array}$ & $\begin{array}{c}\text { Dyed fabric } \\
\text { with henna dye }\end{array}$ & $\begin{array}{c}\text { Dyed fabric with } \\
\text { onion skin dye }\end{array}$ \\
\hline $100 \%$ cotton & 6.1 & 6.8 & 5.9 & 6.5 \\
\hline $100 \%$ PET & 1.9 & 2.1 & 1.8 & 1.9 \\
\hline $35 \%$ cotton / 65\% PET & 2.4 & 4.1 & 2.0 & 3.9 \\
\hline L.S.D. $0.05 \%$ & 0.20 & 0.20 & 0.20 & 0.20 \\
\hline
\end{tabular}

L.S.D. $0.05 \%$. = Least significant difference at $0.05 \%$ level.

Table 6. Shrinkage (\%) of dyed fabrics with henna and onion skin dye (effect of fabric material).

\begin{tabular}{|l|c|c|c|c|}
\hline \multirow{2}{*}{ Treatment } & \multirow{2}{*}{$\begin{array}{c}\text { Fabric } \\
\text { direction }\end{array}$} & $\begin{array}{c}100 \% \\
\text { Cotton }\end{array}$ & $\begin{array}{c}35 \% \text { Cot } / \\
65 \% \text { PET }\end{array}$ & $\begin{array}{c}100 \% \\
\text { PET }\end{array}$ \\
\cline { 1 - 2 } Dyeing with henna dye & \multirow{2}{*}{ Width } & 6.1 & 1.9 & 2.4 \\
\cline { 1 - 1 } Dyeing with onion skin dye & & 6.8 & 2.1 & 4.1 \\
\hline \multirow{2}{*}{ Dyeing with henna dye } & \multirow{2}{*}{ Length } & 5.9 & 1.8 & 2.0 \\
\cline { 5 - 6 } Dyeing with onion skin dye & & 6.5 & 1.9 & 3.9 \\
\hline \multirow{2}{*}{ L.S.D. $0.05 \%$} & & 0.188 & 0.188 & 0.188 \\
\hline
\end{tabular}

L.S.D. $0.05 \%$. = Least significant difference at $0.05 \%$ level.

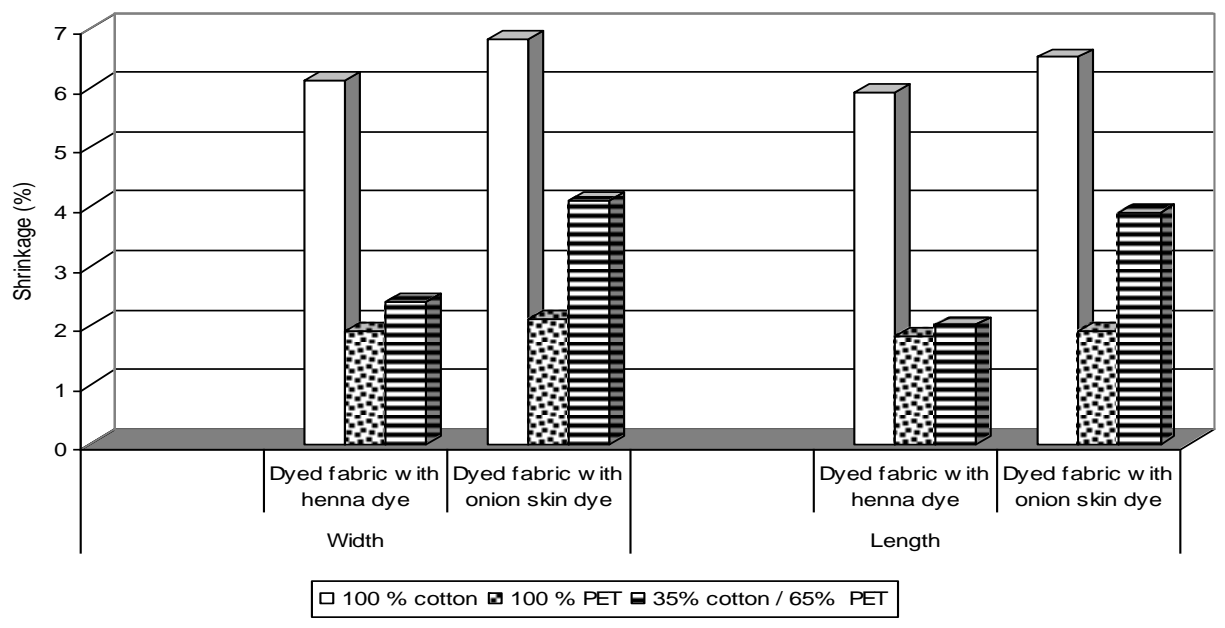

Fig. 5. Shrinkage (\%) of dyed fabrics with henna and onion skin dye (effect dye type) 


\section{Color strength (K/S) and color fastness properties (wash, light and perspiration) for the different fabric materials after dyeing with henna and onion skin dyes:}

\section{Color strength:}

The color strength for the three fabric types is presented in Tables 7 and 8. It is quite obvious that, both dyes considered in this study showed similar trends. Where color strength $(\mathrm{K} / \mathrm{S})$ values were the highest for $100 \%$ cotton fabric and followed, in a descending order by the 35\% cotton/65 \% PET fabric and $100 \%$ PET. On the other hand, from the values of color strength $(K / S)$ it is clear that henna dye was more suitable for dyeing $100 \%$ cotton fabric than dyeing the other two fabric materials (100\% PET fabric and $35 \%$ cotton / $65 \%$ PET fabric). However, it was apparent that onion skin dye revealed slightly higher color strength values for $100 \%$ PET fabric and $35 \%$ cotton/ 65\% PET fabric relative to the henna dye. While henna dye by contrast revealed higher color strength for the $100 \%$ cotton fabric relative to onion skin dye.

Table 7. Color strength (K/S) of fabrics dyed with henna and onion skin dyes (effect of dye type).

\begin{tabular}{|l|c|c|}
\hline \multicolumn{1}{|c|}{ Fabric type } & $\begin{array}{c}\text { Dyed fabric with henna } \\
\text { dye }\end{array}$ & Dyed fabric with onion skin dye \\
\hline $100 \%$ cotton & 8.7 & 7.041 \\
\hline $100 \%$ PET & 1.8135 & 2.915 \\
\hline $35 \%$ cotton / 65\% PET & 2.759 & 4.238 \\
\hline L.S.D. $0.05 \%$ & 0.1990 & 0.200 \\
\hline
\end{tabular}

L.S.D. $0.05 \%$. = Least significant difference at $0.05 \%$ level.

Table 8. Color strength (K/S) of fabrics dyed with henna and onion skin dyes (effect of fabric material).

\begin{tabular}{|l|c|c|c|}
\hline Treatment & $100 \%$ Cotton & $35 \%$ Cot $/ 65 \%$ PET & $100 \%$ PET \\
\hline Dyeing with henna dye & 8.7 & 1.8 & 2.8 \\
\hline Dyeing with onion skin dye & 7.05 & 2.9 & 4.25 \\
\hline L.S.D. $0.05 \%$ & 0.190 & 0.188 & 0.200 \\
\hline
\end{tabular}

L.S.D. $0.05 \%$. = Least significant difference at $0.05 \%$ level. 


\section{Light fastness:}

It is evident from the data of Tables 9 and 10 that , fabrics included in this study seemed to have high light fastness $(4 / 5)$ in case of dyeing them with both natural dyes (henna and onion skin), without any obvious differences.

\section{Wash fastness (color change and staining):}

The fastness in such a case was indicated by both color change and color staining. Tables 9 and 10 showed that as regard to color staining the three kinds of fabrics were found to have high fastness to wash (4/5) when both natural dyes (henna and onion skin ) were applied. Color change for henna dye proved to have the highest fastness to wash (3/5 to 4/5) compared with the onion skin dye (2/5 to 3/5). This may be due to that these natural dyes (Lawson and anthocyanin ) contain functional groups capable of forming covalent bonds with active sites in the fibers such as hydroxyl group in the cotton, such bond formation between the functional groups and the substrate results in high wash fastness (Vigo, 1994).

\section{Alkali perspiration fastness (color change and staining):}

Tables 9 and 10 reveal that as for henna dye, alkali perspiration fastness which is indicated by color change and color staining were not high (2/5). However, onion skin dye showed lower values (3/5) for all fabric types, considered in the study.

\section{Acidic perspiration fastness (color change and staining):}

Fastness to acidic perspiration indicated by color change and color staining values for all three types of fabric materials are presented in tables 9 and 10. The results showed that generally henna dye seams to have high color staining values $(3 / 5$ to $4 / 5)$, relative to the color staining of the onion skin dye $(3 / 5$ to $2 / 5)$. This pattern was true for all used fabric materials. On the other hand, when color change was considered as an indication for fastness to acidic perspiration both natural dyes appeared to have poor effect in this regard (3/5) for all the three types of fabric materials. 
Table 9. Color fastness properties (wash, light and perspiration) of fabrics dyed with henna dye.

\begin{tabular}{|c|c|c|c|c|c|c|c|c|c|c|c|c|}
\hline \multirow{3}{*}{$\begin{array}{l}\text { Color } \\
\text { properties }\end{array}$} & \multicolumn{4}{|c|}{$100 \%$ cotton } & \multicolumn{4}{|c|}{$100 \%$ polyester } & \multicolumn{4}{|c|}{$35 \%$ cotton / $65 \%$ polyester } \\
\hline & \multicolumn{2}{|c|}{ Weft } & \multicolumn{2}{|c|}{ Warp } & \multicolumn{2}{|c|}{ Weft } & \multicolumn{2}{|c|}{ Warp } & \multicolumn{2}{|c|}{ Weft } & \multicolumn{2}{|c|}{ Warp } \\
\hline & $\begin{array}{c}\text { Undyed } \\
\text { fabric }\end{array}$ & $\begin{array}{l}\text { Dyed } \\
\text { fabric }\end{array}$ & $\begin{array}{c}\text { Undyed } \\
\text { fabric }\end{array}$ & $\begin{array}{l}\text { Dyed } \\
\text { fabric }\end{array}$ & $\begin{array}{c}\text { Undyed } \\
\text { fabric }\end{array}$ & $\begin{array}{l}\text { Dyed } \\
\text { fabric }\end{array}$ & $\begin{array}{c}\text { Undyed } \\
\text { fabric }\end{array}$ & $\begin{array}{l}\text { Dyed } \\
\text { fabric }\end{array}$ & $\begin{array}{c}\text { Undyed } \\
\text { fabric }\end{array}$ & $\begin{array}{l}\text { Dyed } \\
\text { fabric }\end{array}$ & $\begin{array}{l}\text { Undyed } \\
\text { fabric }\end{array}$ & $\begin{array}{l}\text { Dyed } \\
\text { fabric }\end{array}$ \\
\hline Light fastness & $4 / 5$ & $4 / 5$ & $4 / 5$ & $4 / 5$ & $5 / 5$ & $4 / 5$ & $5 / 5$ & $4 / 5$ & $5 / 5$ & $4 / 5$ & $5 / 5$ & $4 / 5$ \\
\hline Wash fastness St. & $4 / 5$ & $4 / 5$ & $5 / 5$ & $4 / 5$ & $5 / 5$ & $3 / 5$ & $5 / 5$ & $4 / 5$ & $5 / 5$ & $4 / 5$ & $5 / 5$ & $4 / 5$ \\
\hline Wash fastness CC. & $4 / 5$ & $4 / 5$ & $5 / 5$ & $3 / 5$ & $5 / 5$ & $3 / 5$ & $5 / 5$ & $4 / 5$ & $5 / 5$ & $3 / 5$ & $5 / 5$ & $4 / 5$ \\
\hline Alkali perspiration St & $4 / 5$ & $2 / 5$ & $5 / 5$ & $2 / 5$ & $5 / 5$ & $2 / 5$ & $5 / 5$ & $2 / 5$ & $5 / 5$ & $2 / 5$ & $5 / 5$ & $2 / 5$ \\
\hline Alkali perspiration CC & $5 / 5$ & $2 / 5$ & $5 / 5$ & $2 / 5$ & $5 / 5$ & $2 / 5$ & $5 / 5$ & $2 / 5$ & $5 / 5$ & $3 / 5$ & $5 / 5$ & $3 / 5$ \\
\hline Acidic perspiration St & $5 / 5$ & $3 / 5$ & $5 / 5$ & $4 / 5$ & $5 / 5$ & $4 / 5$ & $5 / 5$ & $2 / 5$ & $5 / 5$ & $3 / 5$ & $5 / 5$ & $4 / 5$ \\
\hline Acidic perspiration CC & $4 / 5$ & $2 / 5$ & $4 / 5$ & $2 / 5$ & $5 / 5$ & $2 / 5$ & $5 / 5$ & $2 / 5$ & $5 / 5$ & $2 / 5$ & $5 / 5$ & $2 / 5$ \\
\hline
\end{tabular}

St $=$ Gray scale for Staining

$\mathrm{CC}=$ Gray scale for color change.

Note: The higher values of color change ranging from $3 / 5$ to $5 / 5$ indicate higher fastness and vice versa. 
Table 10. Color fastness properties (wash, light and perspiration) of fabrics dyed with onion skin dye.

\begin{tabular}{|c|c|c|c|c|c|c|c|c|c|c|c|c|}
\hline \multirow{3}{*}{$\begin{array}{l}\text { Color fastness } \\
\text { properties }\end{array}$} & \multicolumn{4}{|c|}{$100 \%$ cotton } & \multicolumn{4}{|c|}{$100 \%$ polyester } & \multicolumn{4}{|c|}{$35 \%$ cotton / $65 \%$ polyester } \\
\hline & \multicolumn{2}{|c|}{ Weft } & \multicolumn{2}{|c|}{ Warp } & \multicolumn{2}{|c|}{ Weft } & \multicolumn{2}{|c|}{ Weft } & \multicolumn{2}{|c|}{ Warp } & \multicolumn{2}{|c|}{ Weft } \\
\hline & $\begin{array}{c}\text { Undyed } \\
\text { fabric }\end{array}$ & $\begin{array}{l}\text { Dyed } \\
\text { fabric }\end{array}$ & $\begin{array}{c}\text { Undyed } \\
\text { fabric }\end{array}$ & $\begin{array}{l}\text { Dyed } \\
\text { fabric }\end{array}$ & $\begin{array}{c}\text { Undyed } \\
\text { fabric }\end{array}$ & $\begin{array}{l}\text { Dyed } \\
\text { fabric }\end{array}$ & $\begin{array}{l}\text { Undyed } \\
\text { fabric }\end{array}$ & $\begin{array}{l}\text { Dyed } \\
\text { fabric }\end{array}$ & $\begin{array}{c}\text { Undyed } \\
\text { fabric }\end{array}$ & $\begin{array}{l}\text { Dyed } \\
\text { fabric }\end{array}$ & $\begin{array}{l}\text { Undyed } \\
\text { fabric }\end{array}$ & $\begin{array}{l}\text { Dyed } \\
\text { fabric }\end{array}$ \\
\hline Light fastness & $4 / 5$ & $4 / 5$ & $4 / 5$ & $4 / 5$ & $5 / 5$ & $4 / 5$ & $5 / 5$ & $4 / 5$ & $5 / 5$ & $4 / 5$ & $5 / 5$ & $4 / 5$ \\
\hline Wash fastness St. & $4 / 5$ & $4 / 5$ & $5 / 5$ & $4 / 5$ & $5 / 5$ & $4 / 5$ & $5 / 5$ & $4 / 5$ & $5 / 5$ & $4 / 5$ & $5 / 5$ & $4 / 5$ \\
\hline Wash fastness CC. & $4 / 5$ & $3 / 5$ & $5 / 5$ & $2 / 5$ & $5 / 5$ & $2 / 5$ & $5 / 5$ & $3 / 5$ & $5 / 5$ & $2 / 5$ & $5 / 5$ & $2 / 5$ \\
\hline Alkali perspiration St & $5 / 5$ & $3 / 5$ & $5 / 5$ & $3 / 5$ & $5 / 5$ & $3 / 5$ & $5 / 5$ & $3 / 5$ & $5 / 5$ & $2 / 5$ & $5 / 5$ & $3 / 5$ \\
\hline Alkali perspiration CC & $4 / 5$ & $3 / 5$ & $5 / 5$ & $3 / 5$ & $5 / 5$ & $3 / 5$ & $5 / 5$ & $3 / 5$ & $5 / 5$ & $3 / 5$ & $5 / 5$ & $3 / 5$ \\
\hline Acidic perspiration St & $5 / 5$ & $3 / 5$ & $5 / 5$ & $2 / 5$ & $5 / 5$ & $3 / 5$ & $5 / 5$ & $3 / 5$ & $5 / 5$ & $3 / 5$ & $5 / 5$ & $3 / 5$ \\
\hline Acidic perspiration CC & $4 / 5$ & $3 / 5$ & $4 / 5$ & $2 / 5$ & $5 / 5$ & $3 / 5$ & $5 / 5$ & $3 / 5$ & $5 / 5$ & $3 / 5$ & $5 / 5$ & $3 / 5$ \\
\hline
\end{tabular}

St $=$ Gray scale for Staining.

$\mathrm{CC}=$ Gray scale for color change.

Note: The higher values of color change ranging from $3 / 5$ to $5 / 5$ indicate higher fastness and vice versa. 


\section{CONCLUSION}

Dyeing all fabric types (100 \% cotton, $100 \%$ PET and $35 \%$ cotton / $65 \%$ PET blend) with henna and onion skin at room temperature $\left(30^{\circ} \mathrm{C}\right)$ in a closed dyeing system generally keep the fabric strength from deterioration. Elongation \% was not noticeably affected, while shrinkage \% after dyeing with henna was lower than that dyed with onion skin dye for both directions (width and length). On the other hand, the color strength values (K/S) for both dyes (henna and onion skin) was the highest in case of $100 \%$ cotton, followed in a descending order by $35 \%$ cotton / $65 \%$ PET blend and $100 \%$ PET. Generally all fabric types included in this study showed high light and high wash fastness, while they had low alkali and acid perspiration fastness for both dyes of henna and onion skin. It is worthwhile to mention that this study revealed that using a temperature higher than $30^{\circ} \mathrm{C}$ in the dyeing process system was not suitable for dyeing these kinds of fabrics with henna and onion skin dyes so it is not necessary and not required. However, this method of dyeing was economically by saving the energy consumption and friendly for the environment by using the natural dyes.

\section{REFERENCES}

1. AATCC 1998. American Association for Textile Chemist and Colorist. 15-1960 \& 36-1961.

2. A.S.T.M. (American Society for Testing and Materials). 1972, 1986 and 1993. Standard on textile materials.D: 1682, D: 2053 and D: 2288.

3. Botros , R. M., Badria F.A. and G. T. Maatooq. 2004. Antioxidant and immuonomudolatory constituents of henna leaves. Z. Naturforsch, 59c : 468-476.

4. El-Nagar, Kh, H. Suzan, , Amal M. and A. Ramadan. 2005. Mechanical properties and stability to light exposure for dyed Egyptian cotton fabrics with natural and synthetic dyes. Polymer - Plastic Technology and Engineering, 44: 1269-1279.

5. Isharat, S. A. 1993. Revival of natural dyes in Asia. Journal of the Society of Dyers and Colourists, 109 (1) : 13 .

6. Little, T.M. and F. J. Hills. 1978. Agricultural Experimentation Design and Analysis. John Wiley and Sons. New York, Chichester, Brisbane, Toronto pp. 350.

7. Miksovsky F. 1980. Method for producing stain resistant polyamide fibers Journal of the Society of Dyers and Colourists; $96: 347$.

8. NOVA Teacher's Guide. 2005. Viking deception. www.Pbs.org/nova/vinland, pp.3/5. 
9. Rehsi, S. S. and E.D. Daruvala. 1957.Utilization of henna leaves for dyeing textiles. Journal of Scientific and Industrial Research. 16 (2):428.

10. Routledge, D. and P. Kegan. 1979. The weaving, spinning and dyeing book, Chapter I, Rachel brown,London.

11. Sidney, G. C. 1978. The textile industry, environmental control and energy conservation, Nayes Data Corporation, New Jersey U.S.A., pp.310-316.

12. Swiderski, Z. 1981. The modern dyeing systems for blends of polyester and cellulose fibers. Przeglad Wlokienniczy, No. 2 : 87-91.

13. Taylor, G. W. 1986. Rev. Prog. Coloration. 16:53. (Cited From) Hany, M. H.,1998. Dyeing of wool and silk using some natural dyes. M.Sc. Thesis, Faculty of Applied Arts, Helwan University.

14. Vigo, T. L. 1994. Textile processing and properties; preparation, dyeing, finishing and performance. Southern Regional Research Center, New Orleans, USA, Ch. 3. 


\title{
إمكانية صبغ بَفْض الخامات النسيجية (قطن، بولى استر ، قطن / بولَى استر)

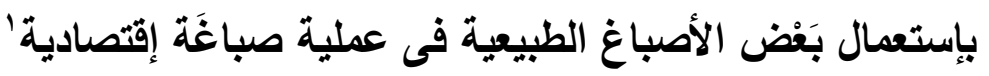

\author{
أمل صابر محمد \\ معهُ بحوث القطن - مركز البحوث الزراعية - جيزة - مصر
}

يهدف هذا البحث إلى دراسة قابلية صباغة بعض الخامات النسيجية ( . . 1 \% القطن ، . . 1\%

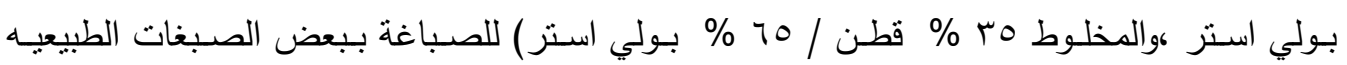

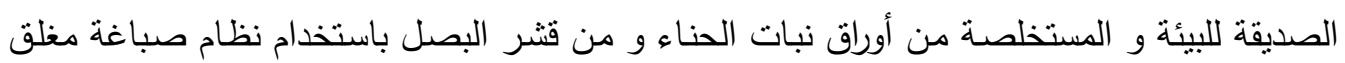

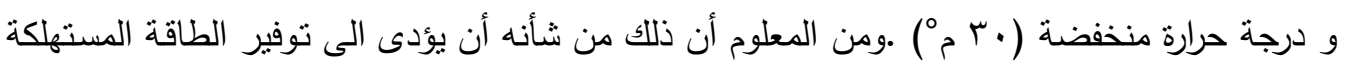

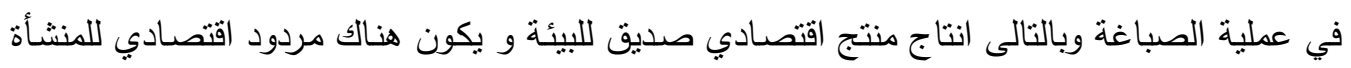
الصناعية ومردود بيئي يعود علي المجتمع كله ، مما يفيد كل من مربي ومصنعي القطن . أوضحت التتائج مايلي:

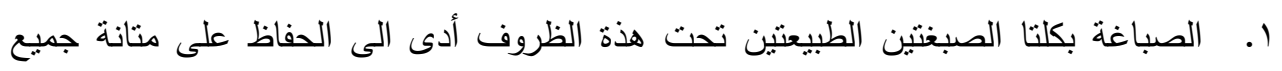

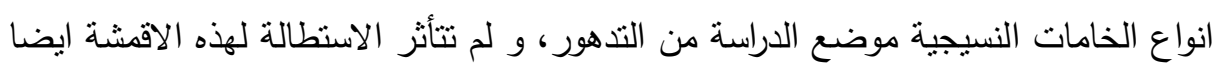
r. وجد أن درجة انكماش هذه الاقشة بعد الصباغة بالحناء أقل من درجة انكماش الاقشة بعد

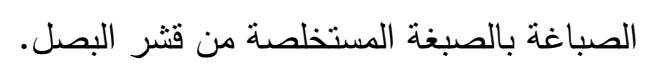

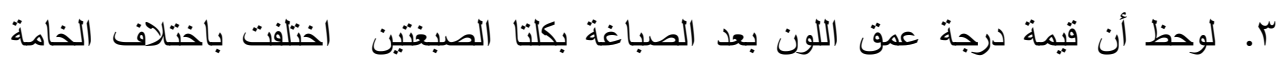

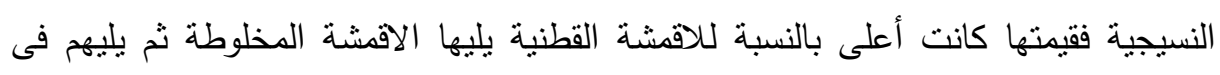
ترتيب نتازلى اقمشة البولى استر.

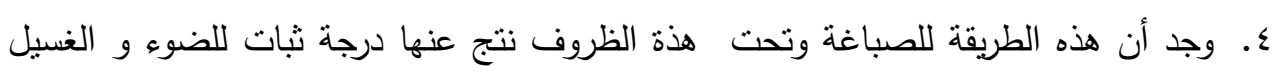


الحامضى و القاعدى منخفضة.

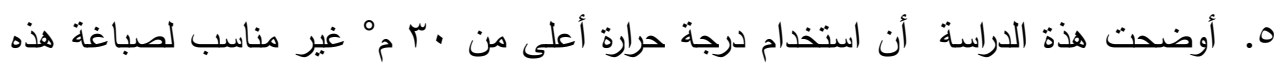
الخامات النسيجية و يؤدى الى تشبيح الصبغة و بالتالى عدم قبول المظهربعد الصبغ.



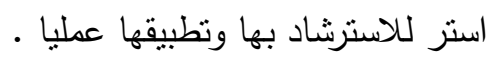

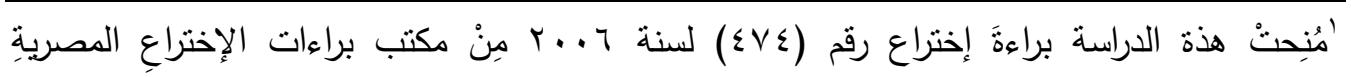
باكاديمية البحث العلمى و التكنولوجيا. 